\title{
PHYTOCHEMICAL PROFILE, ANTIOXIDANT, ANALGESIC AND HYPOLIPIDAEMIC EFFECTS OF EPHEDRA ALATA DECNE. FEMALE CONES EXTRACT
}

\author{
ATEF CHOUIKH ${ }^{1,2}$ \\ ${ }^{1}$ Biology Department, Faculty of Natural Science and Life, El Oued University, Algeria \\ ${ }^{2}$ Laboratory Biology, Environment and Health (LBEH), El Oued University, Algeria \\ *corresponding author: chouikhateff@gmail.com
}

Manuscript received: April 2020

\begin{abstract}
The aim of this study is the estimation of the antioxidant, analgesic and hypolipidemic effects and the chromatographic analysis of the extract of female cones of Ephedra alata which is growing in South East Algeria. The extract of E. alata showed better inhibition of $\mathrm{DPPH} \bullet$ radical, the highest reductive activity and gave the best protection of erythrocytes. The HPLC analyses has identified eight phenolic compounds: gallic acid, chlorogenic acid, vanillic acid, vanillin, p-coumaric acid, rutin, naringenin and quercetin. The results of the protective effect of hyperlipidaemia caused by Triton X-100 showed that there are noticeable changes in the biochemical and lipid parameters, also for the parameters of oxidative stress in the group exposed to Triton X-100. Also, the treatment with the methanol extract of E. alata yielded similar results to the control batches by normalizing and decreasing the biochemical, stress and lipid parameters. The histological study confirmed the biochemical results. According to the results of the analgesic activity, the extract of $E$. alata induced a significant decrease in abdominal writhings compared to the control group and the values obtained are very close to those obtained with indomethacin.
\end{abstract}

\section{Rezumat}

Scopul acestui studiu a fost evaluarea efectelor antioxidante, analgezice, hipolipemiante şi analiza cromatografică a extractului de conuri femele de Ephedra alata, din sud-estul Algeriei. Extractul de E. alata a arătat o inhibiție mai bună a radicalului DPPH $\bullet$, cea mai ridicată activitate reducătoare și a oferit cea mai bună protecție asupra eritrocitelor. Analizele HPLC au identificat opt compuşi fenolici: acid galic, acid clorogenic, acid vanilic, vanilină, acid p-cumaric, rutină, naringenină şi quercetină. Rezultatele efectului protector asupra hiperlipemiei cauzate de Triton X-100 au arătat că există modificări vizibile ale parametrilor biochimici și lipidici, de asemenea, pentru parametrii stresului oxidativ din grupul expus la Triton X-100. De asemenea, tratamentul cu extract metanolic de E. alata a scăzut parametrii biochimici, stresul oxidativ și parametrii lipidici. Studiul histologic a confirmat rezultatele biochimice. Acțiunea analgezică a extractului de E. alata a indus o scădere semnificativă a contorsiunilor comparativ cu grupul martor și valorile obținute sunt foarte apropiate de cele obținute în cazul administrării de indometacin.

Keywords: Ephedra alata, HPLC, hyperlipidaemia, analgesic activity, antioxidant activity

\section{Introduction}

The therapeutic use of medicinal plants is very present in certain countries of the world and especially in the developing countries, in the absence of a modern medical system [48]. The abundance of active ingredients gives the plant remarkable pharmacological properties, which could justify its multiple therapeutic indications and for which it is used in traditional therapy [27]. In Africa, where herbal medicines are still used by many populations in health care [26]. In Algeria, E. alata is used against influenza, whooping cough and general weakness in herbal tea and by inhalation as well as in the form of nasal drops against colds [37]. The stem of Ephedra alata contains alkaloids: ephedrine and pseudo ephedrine which are used for the treatment of cancer, inflammatory diseases, asthma and viral diseases. The use of this plant is also known to be associated with gastrointestinal and psychiatric manifestations [40].
These effects are the reasons why the use of Ephedra is recommended only for acute situations in traditional Chinese medicine and contraindicated for long-term use [9].

On the other hand, the Ephedra alata has been shown to have high antiviral activity against HSV (Herpes simplex virus). The aqueous extract of this plant which collected from Egypt has significant inhibition potential in vitro and in vivo against the growth and production of aflatoxins by Aspergillus flavus [3, 4].

The objective of this work is to evaluate the antihyperlipidaemic, analgesic and antioxidant activities and chromatographic analysis by HPLC of the female cones extract of Ephedra alata to avoid the toxicity of stems of this plant and search for less toxic and effective organs. 


\section{Materials and Methods}

\section{Materials}

Plant material. The female cones of Ephedra alata subsp. alenda were collected on 24 March 2018 Hassi Khalifa (El Oued, Southeast Algeria, 33 $40^{\prime} 42^{\prime \prime} \mathrm{N}$ and $\left.7^{\circ} 13 ' 35^{\prime \prime E}\right)$. The drying was performed at room temperature, protected from light and moisture. After drying, the female cones were crushed and stored in a dry place.

Animals. The study is carried out on male rats weighing $140 \pm 160 \mathrm{~g}$, purchased from a farm of the central pharmacy of Tunis (SIPHAT). They are housed at a temperature of $22 \pm 1{ }^{\circ} \mathrm{C}$ with an alternation of 12 hours of lighting and 12 hours of darkness, the relative humidity being close to $40 \%$. The rats received a balanced diet of proteins, lipids, carbohydrates, vitamins and trace elements of the animal nutrition company (SNA, Sfax, Tunisia). Throughout the experimental period (15 days), the animals were treated according to experimentation procedures and experimental protocols of the European Communities Council Directive of 24 November 1986 (86/609/EEC).

Chemicals. Triton X-100, ascorbic acid, gallic acid, 2, 2-diphenyl-1-picrylhydrazyl (DPPH), potassium ferricyanide $\left(\mathrm{K}_{4} \mathrm{Fe}(\mathrm{CN})_{6}\right)$, quercetin, chlorogenic acid, p-coumaric acid, vanillic acid, rutin, vanillin and naringenin were procured from Sigma-Aldrich (USA). Aluminium chloride $\left(\mathrm{AlCl}_{3}\right)$, ferric chloride $\left(\mathrm{FeCl}_{3}\right)$, sodium carbonate $\left(\mathrm{Na}_{2} \mathrm{CO}_{3}\right)$, acetic acid and trichloroacetic acid were purchased from Prolabo (USA). FolinCiocalteu reagent (FCR), methanol (99\%) and hydrogen peroxide $\mathrm{H}_{2} \mathrm{O}_{2}(30 \%)$ were obtained from Biochem Chemopharma Co (France). All other reagents used were of analytical grade, acetonitrile of HPLC gradient grade was purchased from Sigma Aldrich (USA).

Preparation of the extract. Ten grams of the dry plant were macerated with $150 \mathrm{~mL}$ of methanol (99\%) at room temperature in dark for 24 hours. After filtration, the solvent was evaporated to dryness under reduced pressure in a rotary evaporator at $50^{\circ} \mathrm{C}$ [10], for obtaining the dry extract.

Spectrophotometric assays

Determination of total phenolic contents. The total phenolic contents of the crude extract were determined according to the Folin-Ciocalteu's phenol reagent method [46] with some modification; we mixed $0.2 \mathrm{~mL}$ of the extract with $1 \mathrm{~mL}$ of Folin-Ciocalteu reagent (10\%), then we added 0.8 of sodium carbonate solution (7.5\%). After stirring the test tubes, the absorbance was measured at $765 \mathrm{~nm}$, after $30 \mathrm{~min}$, using the spectrophotometer UV. The calibration curve was prepared with gallic acid solutions in the concentration range $0.02-0.12 \mathrm{mg} / \mathrm{mL}$. The total phenolic content was expressed as $\mathrm{mg}$ of gallic acid equivalents in $1 \mathrm{~g}$ of extract.

Determination of flavonoids contents. According to [6], we blended $1 \mathrm{~mL}$ of the sample solution with $1 \mathrm{~mL}$ of $\mathrm{AlCl}_{3}$ solution (2\%). After stirring the test tubes, after 10 - $15 \mathrm{~min}$ at room temperature, the absorbance was measured at $430 \mathrm{~nm}$. The calibration curve was prepared with quercetin solutions in the concentration range of $0.03-0.1 \mathrm{mg} / \mathrm{mL}$. The content of flavonoids in the extract was expressed as $\mathrm{mg}$ of quercetin $\mathrm{E} / \mathrm{g}$ of extract.

\section{Evaluation of Antioxidant activity}

DPPH scavenging assay

The DPPH scavenging activity of the extracts was measured by using the modified method of [7]. A volume of $1 \mathrm{~mL}$ of extract at different concentrations $(2-50 \mu \mathrm{g} / \mathrm{mL}$ ) was added to $1 \mathrm{~mL}$ of DPPH solution $\left(0.1 \times 10^{-3} \mathrm{M}\right)$ in methanol. After incubation for 15 min at room temperature, the absorbance of the reaction mixture was measured at $517 \mathrm{~nm}$.

The percentage of inhibition was calculated by using the following formula:

$\mathrm{DPPH}$ radical scavenging inhibition $\%=\left[\left(\mathrm{Abs}_{\mathrm{control}}\right.\right.$ -

$$
\left.\left.\mathrm{Abs}_{\text {sample }}\right) / \mathrm{Abs}_{\text {control }}\right] \times 100 \text {, }
$$

The $\mathrm{IC}_{50}$ values were calculated from the linear equation of scavenging activity against the concentrations of the samples. $\mathrm{IC}_{50}$ is defined as the total antioxidant necessary to decrease the initial DPPH radical $50 \%$ [25].

\section{Haemolysis assay}

This test is used to determine the ability of the plant extracts to protect the erythrocyte blood cells from damage or disruption of the cell membrane after exposing them to oxidative stress and free radicals by measuring the percentage of dissolved erythrocytes [12].

According to [11], a volume of $40 \mu \mathrm{L}$ of human erythrocytes of was mixed with $2 \mathrm{~mL}$ of different concentrations $(0.25-1 \mathrm{mg} / \mathrm{mL})$ of extract and conserved for $5 \mathrm{~min}$ at $37^{\circ} \mathrm{C}$. Then, we added $40 \mu \mathrm{L}$ of $\mathrm{H}_{2} \mathrm{O}_{2}(30 \times$ $\left.10^{-3} \mathrm{M}\right), 40 \mu \mathrm{L}$ of $\mathrm{FeCl}_{3}\left(80 \times 10^{-3} \mathrm{M}\right)$ and $40 \mu \mathrm{L}$ of ascorbic acid solution $\left(50 \times 10^{-3} \mathrm{M}\right)$ respectively.

After 1 hour of incubation at $37^{\circ} \mathrm{C}$, the mixture was centrifuged with $700 \mathrm{rot} / \mathrm{min}$ for $10 \mathrm{~min}$. The absorbance of the supernatant was read at $\lambda=540 \mathrm{~nm}$.

The percentage of haemolysis was determined using the following formula:

$$
\text { Haemolysis\% }=\left(\mathrm{Abs}_{\text {control }} / \mathrm{Abs}_{\text {sample }}\right) \times 100,
$$

Reducing power assay

The presence of antioxidants in the extracts resulted in reduction of the ferric cyanide complex $\left(\mathrm{Fe}^{3+}\right)$ to the ferrous cyanide form $\left(\mathrm{Fe}^{2+}\right)$ [15].

A volume of $0.5 \mathrm{~mL}$ of the different concentrations $(0.01-0.1 \mathrm{mg} / \mathrm{mL})$ of the extract was added to $1.25 \mathrm{~mL}$ of a phosphate buffer $(0.2 \mathrm{M}, \mathrm{pH} 6.6)$ mixed with $1.25 \mathrm{~mL}$ of potassium ferricyanide $(1 \%)$. The mixture was incubated in a hot bath at $50^{\circ} \mathrm{C}$ for $20 \mathrm{~min}$, the reaction is stopped by adding $1.25 \mathrm{~mL}$ of trichloroacetic acid (10\%), the tubes were then centrifuged at $3000 \mathrm{rpm}$ for $10 \mathrm{~min} .1 .25 \mathrm{~mL}$ of the supernatant, was mixed with $0.25 \mathrm{~mL}$ of $\mathrm{FeCl}_{3}(0.1 \%)$ and $1.25 \mathrm{~mL}$ of 
distilled water, and the optical density was read at $700 \mathrm{~nm}$ [43].

Chromatographic analysis by High-Performance Liquid Chromatography (HPLC)

A high performance liquid chromatography (HPLC) system, type Shimadzu LC 20 AL equipped with the universal injector (Hamilton $25 \mu \mathrm{L}$ ), an analytical column used was a Shim-pack VP-ODS C18 (4.6 $\mathrm{mm} \times 250 \mathrm{~mm}, 5 \mu \mathrm{m}$ ), type (Shimadzu). UV-VIS detector SPD 20A (Shimadzu) was used [49]. $20 \mu \mathrm{L}$ of plant extract solution was injected into the flow of mobile phase [25]. The separated compounds were determined using the column for 40 - $50 \mathrm{~min}$, with detection at $\lambda=268 \mathrm{~nm}$.

In this study the quantification of separated peaks was performed by calibration with standards.

Acute toxicity

Thirty rats were fasted for 24 hour and divided into 4 groups, each group containing 6 animals. All the groups were orally fed with the extract of E. alata suspended in $1 \%$ carboxy methyl cellulose in increasing doses of $10,50,100$ and $200 \mathrm{mg} / \mathrm{kg}$. The animals were observed for $2 \mathrm{~h}$ for any behavioural changes, neurological and autonomic profiles, or cases of death after $24 \mathrm{~h}$ and $72 \mathrm{~h}$ [54].

Evaluation of the protective effect of methanol extract of Ephedra alata due to hyperlipidaemia caused by Triton $X-100$

Acute hyperlipidaemia in animal was induced with Triton X-100 [42].

Experimental protocol

Thee rats were divided into 4 groups of 6 individuals each: The first group received distilled water by gavage (control group). The second group received by gavage a solution of the methanol extract of Ephedra alata, $50 \mathrm{mg} / \mathrm{kg}$ of body weight (EME. alata group). The third group received a single dose of Triton X-100 (100 mg/kg bw) (Hyp group). The fourth group was pre-treated daily with both methanolic received both extract of E. alata $50 \mathrm{mg} / \mathrm{kg}$ bw and Triton X-100 (100 mg/kg bw) (EME. alata + Hyp group).

Blood samples

The blood was collected in tubes with EDTA and then centrifuged for $15 \mathrm{~min}$ at $4000 \mathrm{rpm}$. The plasma was collected and frozen at $-80^{\circ} \mathrm{C}$ until it was used for the determination of certain biochemical and enzymatic parameters.

Organs samples

The liver was removed and weighed. Part of this organ was fixed in alcoholic Bouin to carry out histological studies. The other part was frozen at $-80^{\circ} \mathrm{C}$ for the study of oxidative stress.

Oxidative stress assessment

The parameters assessing the oxidative stress were the extraction of the cytosol, the determination of total tissue proteins and the tissue MDA; for the determination of the activity of tissue antioxidant enzymes we determined the superoxide dismutase
(SOD) activity, catalase activity (CAT) and glutathione peroxidase activity (GPx) [39].

Determination of biochemical parameters of plasma The parameters assessing liver function measured in this study in plasma were aspartate aminotransferase (ASAT) and alanine aminotransferase (ALAT). The parameters estimate of lipid plasma parameters were the total cholesterol, HDL and LDL-cholesterol, triglyceride [19].

Histological study

During this study, we used a technique previously described [16]. The preparation of cuts was performed using a microtome (Leica) to a thickness of $6 \mu \mathrm{m}$ and the sections were frozen.

The staining of the cuts was haematoxylin-eosin, the haematoxylin colouring the nucleus in blue/purple. On the contrary, eosin is colouring the cytoplasm in pink and the other basic cellular elements in pinkred. The second staining with red-oil $\mathrm{O}$ coloured all lipids [51].

Evaluation of the analgesic power (writhing test)

The acetic-acid writhing test was used to evaluate the analgesic activity of the methanol extract of $E$. alata. Four groups of rats ( $\mathrm{n}=3 \mathrm{per}$ group) were injected with acetic acid $(10 \mathrm{~mL} / \mathrm{kg} \mathrm{bw})$, and the intensity of nociception was quantified by counting the total number of writhes over $30 \mathrm{~min}$. The animals received a dose of methanol extract of $E$. alata extract $(50 \mathrm{mg} / \mathrm{kg} \mathrm{bw})$ or sterile saline (control group, $0.9 \%$, $\mathrm{w} / \mathrm{v}), 30 \mathrm{~min}$ before acetic acid injection. Indomethacin $(10 \mathrm{mg} / \mathrm{kg} \mathrm{bw})$ was used as a reference substance (positive control). The numbers of writhes were counted $5 \mathrm{~min}$ after acetic acid injection for $30 \mathrm{~min}$ [29].

The inhibition percentage of writhing was calculated using the following formula:

$\%$ inhibition of writhing $=[($ Mean number of control - Mean number of test)/Mean number of control] $\times 100$,

Statistical analysis

The results obtained are expressed as mean \pm SEM. Data analysis was performed by using Student's T-test, using SPSS Statistics (version 23.0) at significance level $\mathrm{p}<0.05$.

\section{Results and Discussion}

Determination of total polyphenols and flavonoids in a crude extract

According to the histogram illustrated in Figure 1, we noted that the total polyphenols content $17.65 \pm 0.36$ $\mathrm{mg}$ gallic acid E/g extract and $13.05 \pm 0.78 \mathrm{mg}$ quercetin $\mathrm{E} / \mathrm{g}$ extract expressing the flavonoids.

The content of polyphenols and flavonoids in the methanolic extract is linked to the high solubility of phenols in polar solvents [18].

The variability of the polyphenol content is due to several factors: the drying and extraction conditions in terms of method, time, temperature, particle size, 
solvent, number of extraction steps, expression of results and geographic origin [33].

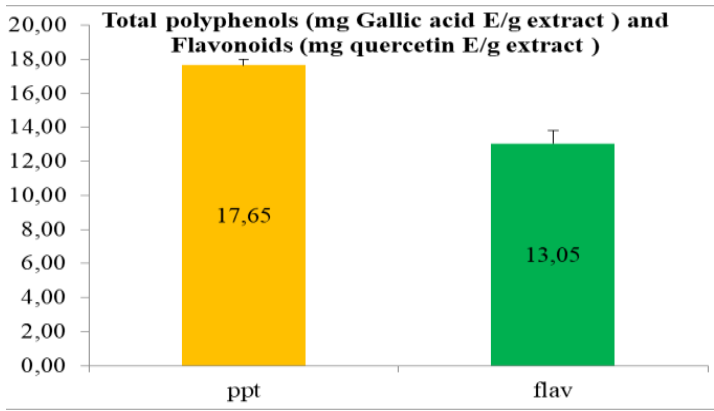

Figure 1.

Polyphenols contents and Flavonoids in methanol extract of Ephedra alata
On the other hand, this variation can be linked to the distribution of secondary metabolites, which change during plant development, environmental stress (drought, poor soil nutrients) as well as intense sunlight [50]. Antioxidant activity

In the DPPH free radical trapping test, ascorbic acid was used as standard. The results are shown in Table I; we noted that the $\mathrm{IC}_{50}$ values were $31.08 \mu \mathrm{g} / \mathrm{mL}$ and $5.41 \mu \mathrm{g} / \mathrm{mL}$ for crude extract and ascorbic acid respectively.

We can see in Table I a reduction of iron for the extract studied, as we have seen that the ascorbic acid has the highest iron-reducing activity.

In our study, the protective effect of erythrocytes at a concentration of $1 \mathrm{mg} / \mathrm{mL}$ is similar in the extract of E. alata and ascorbic acid (Table I).

Table I

Value of antioxidant activity of different tests of the crude extract of Ephedra alata and ascorbic acid

\begin{tabular}{|c|c|c|c|c|c|c|c|c|c|}
\cline { 2 - 9 } & \multirow{2}{*}{$\begin{array}{c}\mathbf{I C}_{\mathbf{5 0}}(\boldsymbol{\mu g} / \mathbf{m L}) \text { DPPH } \\
\text { free radical test }\end{array}$} & \multicolumn{3}{|c|}{$\begin{array}{c}\text { Reducing power absorbance with } \\
\text { concentration }(\mathbf{m g} / \mathbf{m L})\end{array}$} & \multicolumn{4}{|c|}{$\begin{array}{c}\text { \% Haemolysis with concentration } \\
(\mathbf{m g} / \mathbf{m L})\end{array}$} \\
\cline { 3 - 10 } & & $\mathbf{0 . 0 1}$ & $\mathbf{0 . 0 0 5}$ & $\mathbf{0 . 0 7 5}$ & $\mathbf{0 . 1}$ & $\mathbf{0 . 2 5}$ & $\mathbf{0 . 5}$ & $\mathbf{0 . 7 5}$ & $\mathbf{1}$ \\
\hline Ephedra alata extract & 31.08 & 0.16 & 0.448 & 0.705 & 0.963 & 55.46 & 43.68 & 35.12 & 22.27 \\
\hline Ascorbic acid & 5.41 & 0.196 & 0.576 & 0.790 & 0.91 & 54.06 & 41.68 & 29.29 & 16.38 \\
\hline
\end{tabular}

Regarding the DPPH test, ascorbic acid had a very potent anti-radical activity compared to our extracts. Also, we noticed a remarkable anti-radical activity for Ephedra alata extract. There is a direct correlation between antioxidant activities and the reducing power of the components of some plants [55].

The extract reduces and discolours the DPPH• radical due to their ability to yield hydrogen to the free radicals produced during peroxidation [24, 56]. Therefore, the antioxidants are considered to be reducers and activators of oxidants [45]. Some previous studies have also shown that the reducing power of a compound can serve as a significant indicator of its potential antioxidant activity $[24,30]$.
The rate of haemolysis is much higher when red blood cells are treated with hydrogen peroxide. This could be attributed to the oxidative nature of hydrogen peroxide and its ability to destroy the cell membrane and consequently the release of haemoglobin from cells. Hydrogen peroxide can also cause toxicity by the hydroxyl radical [28]. $\mathrm{H}_{2} \mathrm{O}_{2}$ can cause the degradation of haemoglobin thus releasing $\mathrm{Fe}^{2+}$ ions. The antihaemolytic activity of the plant extracts may be due to the inhibition of the radical by the bioactive compounds in the extract which neutralize $\mathrm{H}_{2} \mathrm{O}_{2}$ [11]. Chromatographic analysis by HPLC

The result of the separation of methanol extract from Ephedra alata by HPLC is illustrated in the chromatogram (Figure 2).

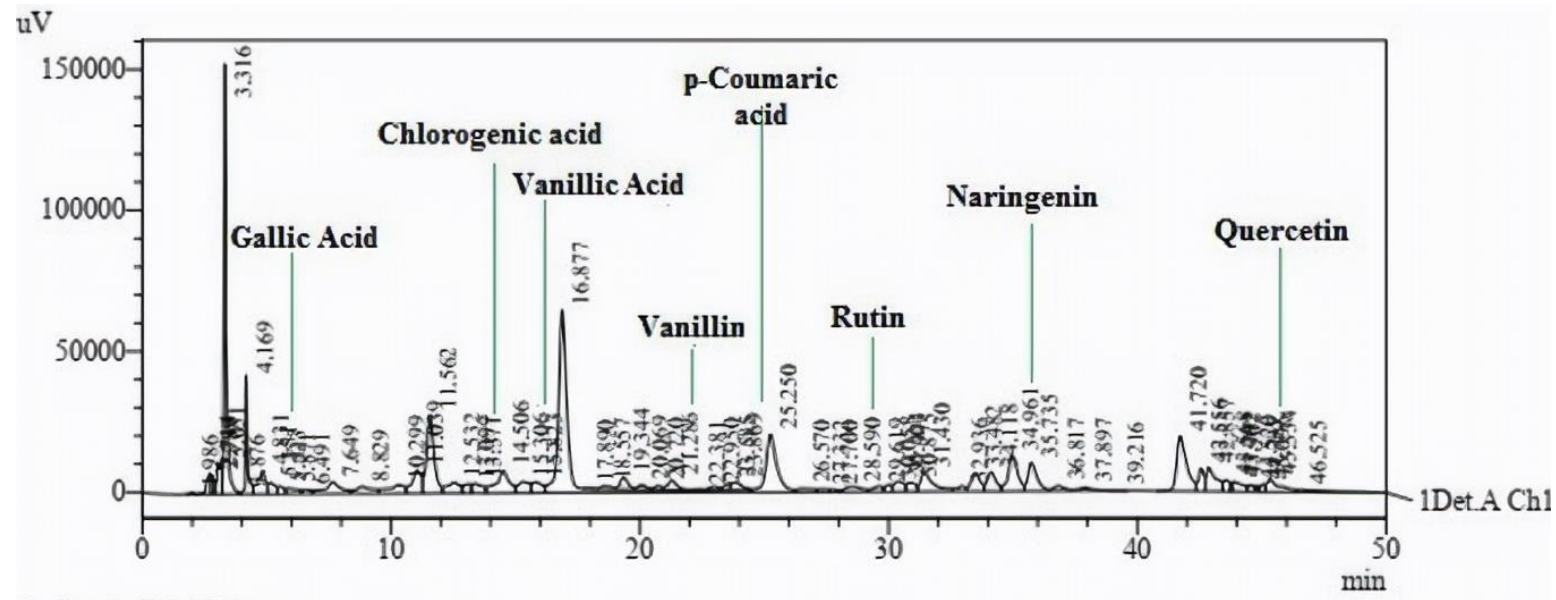

1 Det.A Ch1 / 268nm

Figure 2.

HPLC chromatographic profile of the crude extract of Ephedra alata 
Table II

Retention time and the concentration of some phenolic compounds identified

\begin{tabular}{|c|c|c|c|}
\hline Retention Time (min) & Calibration Curve & Compounds & Concentration $(\boldsymbol{\mu g} / \mathbf{m g}$ extract) \\
\hline 5.151 & $\mathrm{y}=54681 \times \mathrm{x} \mathrm{R}^{2}=9956$ & Gallic acid & 0.289 \\
\hline 13.371 & $\mathrm{y}=21665 \mathrm{x} \mathrm{R}^{2}=9853$ & Chlorogenic acid & 0.926 \\
\hline 15.306 & $\mathrm{y}=56077 \mathrm{x} \mathrm{R}^{2}=9921$ & Vanillic acid & 0.392 \\
\hline 21.286 & $\mathrm{y}=58930 \mathrm{x} \mathrm{R}^{2}=9966$ & Vanillin & 0.276 \\
\hline 23.869 & $\mathrm{y}=49495 \times \mathrm{x} \mathrm{R}^{2}=9961$ & p-Coumaric acid & 0.278 \\
\hline 28.59 & $\mathrm{y}=28144 \mathrm{x} \mathrm{R}^{2}=9869$ & Rutin & 0.637 \\
\hline 34.961 & $\mathrm{y}=19379 \mathrm{x} \mathrm{R}^{2}=9968$ & Naringenin & 3.507 \\
\hline 45.096 & $\mathrm{y}=45378 \times \mathrm{x} \mathrm{R}^{2}=9962$ & Quercetin & 0.166 \\
\hline
\end{tabular}

HPLC identified eight phenolic compounds out of 63 peaks in the crude extract of the Ephedra alata are gallic acid, chlorogenic acid, vanillic acid, vanillin, p-coumaric acid, rutin, naringenin and quercetin. The retention time of these compounds and their concentration is recorded in Table II.

Many studies identified the phenolic compounds in the extract of Ephedra alata by HPLC analysis [23, 34]. These studies are in agreement with our results. Despite the geographic differences of the studied sites, we found that the plant Ephedra alata has the same phenolic profile. This shows that there is no significant qualitative difference. We can explain some of our results as follows: gallic acid allowed the plans to adapt to the climatic conditions, vanillin accelerated the maturity of fruits and $\rho$-coumaric acid contributes to the antioxidant activity [11].

Acute toxicity

In acute toxicity, it was found that E. alata extract was safe at a dose of $100 \mathrm{mg} / \mathrm{kg}$ with no mortality of studied individuals.

Assessment of the protective effect caused by Triton $X$-100 (hyperlipidemia)

Changes in liver enzyme biomarkers in plasma

The effects of Triton X-100 and Ephedra alata on the liver balance in the different studied groups are shown in Figure 3.
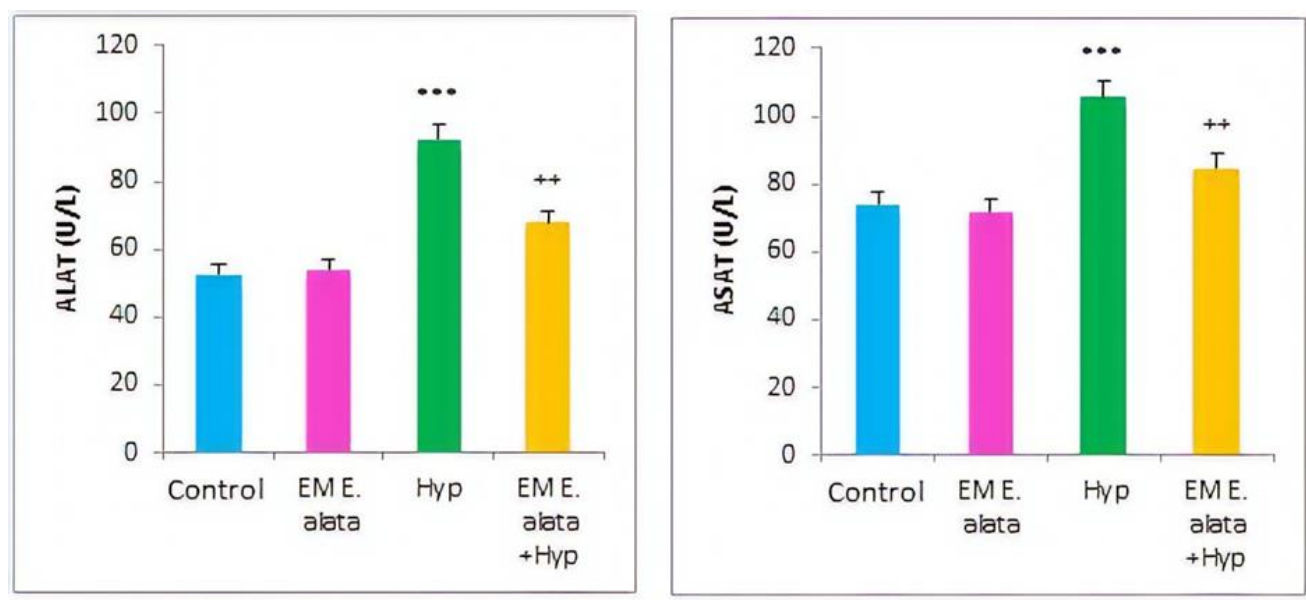

Figure 3.

Variations in ALAT and ASAT enzymes in the control group and the different experimental groups Values represented as mean $\pm \operatorname{SEM}(\mathrm{n}=6) ; * * * \mathrm{p} \leq 0.001$ compared to the normal control group; $++: \mathrm{p} \leq 0.01$ compared to the treated group (Hyp)

The analysis of the results revealed that Triton $\mathrm{X}$ 100 induced a significant increase in the activity of ALAT and ASAT compared to control rats.

Evaluation of lipid parameters at the plasma level The effects of Triton X-100 and the extract of Ephedra alata on the lipid balance in the different lots studied groups are shown in Figure 4.

Our results showed that Triton X-100 induced a significant increase in the concentrations of the lipid parameters at the plasma level in the group of control rats. These changes in the lipid profile could be attributed either to increased hydrolysis of the stored triglyceride via hormone-sensitive lipase activity stimulated by a cyclic adenosine monophosphate dependent protein kinase, or to lipid biogenesis via the cardiac cyclic adenosine monophosphate. On the contrary, in the group Hyp + EM E. alata the cotreatment with the extract of $E$. alata caused the restoration of these parameters in the plasma. However, there were no significant differences observed for total cholesterol in rats treated with $E$. alata extract alone compared to the control group ( $\mathrm{p}>0.05)$. 


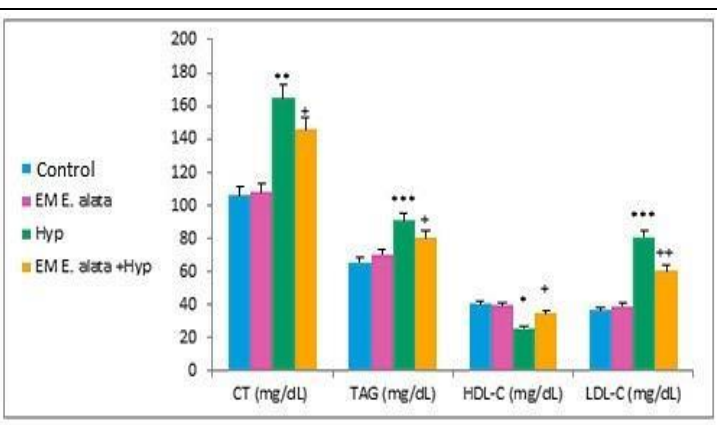

Figure 4.

Variation in serum concentration in CT, TAG, HDL-C and LDL-C in the control group and the experimental groups

Values represented as mean $\pm \operatorname{SEM}(n=6) *^{*}: \mathrm{p} \leq 0.05$; $* *: p \leq 0.01$ and $*^{* *}: \mathrm{p} \leq 0.001$ compared to the normal control group; $+\mathrm{p} \leq 0.05 ;++: \mathrm{p} \leq 0.01$ compared to the treated group (Hyp)

Evaluation of the pro-oxidant/antioxidant profile in the liver

Determination of Malondialdehyde (MDA) tissue The effects of Triton X-100 and the extract of $E$. alata on the tissue parameters of oxidative stress in the different studied groups are shown in Figure 5.

Analysis of these results showed that in rats treated with Triton X-100, hepatic MDA levels increased significantly $(\mathrm{p}<0.001)$ compared to those in the control group, which suggests that there is an increased production of free radicals.

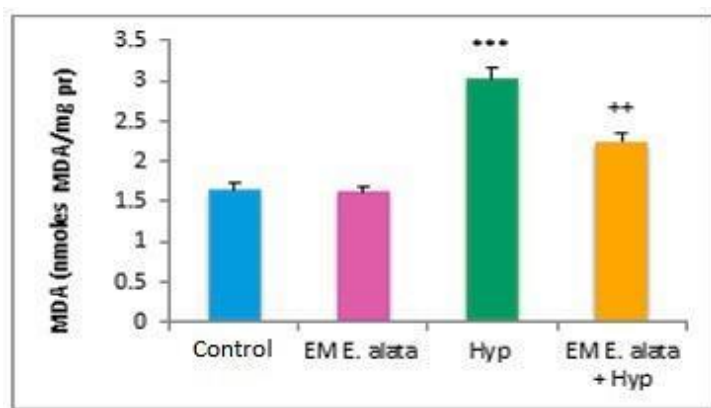

Figure 5.

Variation of malondialdehyde (MDA) of the liver in the control and experimental groups Values represented as mean \pm SEM $(n=6)$; ***: $\mathrm{p} \leq 0.001$ compared to the normal control group; $++: \mathrm{p} \leq 0.01$ compared to the treated group (Нyp)

However, the daily co-administration of the extract of E. alata with Triton X-100 significantly lowered the MDA level $(\mathrm{p}<0.01)$. This result areas for the antioxidant potential of $E$. alata extract.

Variations in the activity of tissue antioxidant enzymes The variations in SOD, CAT and GPx activities of the liver in the control and experimental groups are shown in Figure 6.
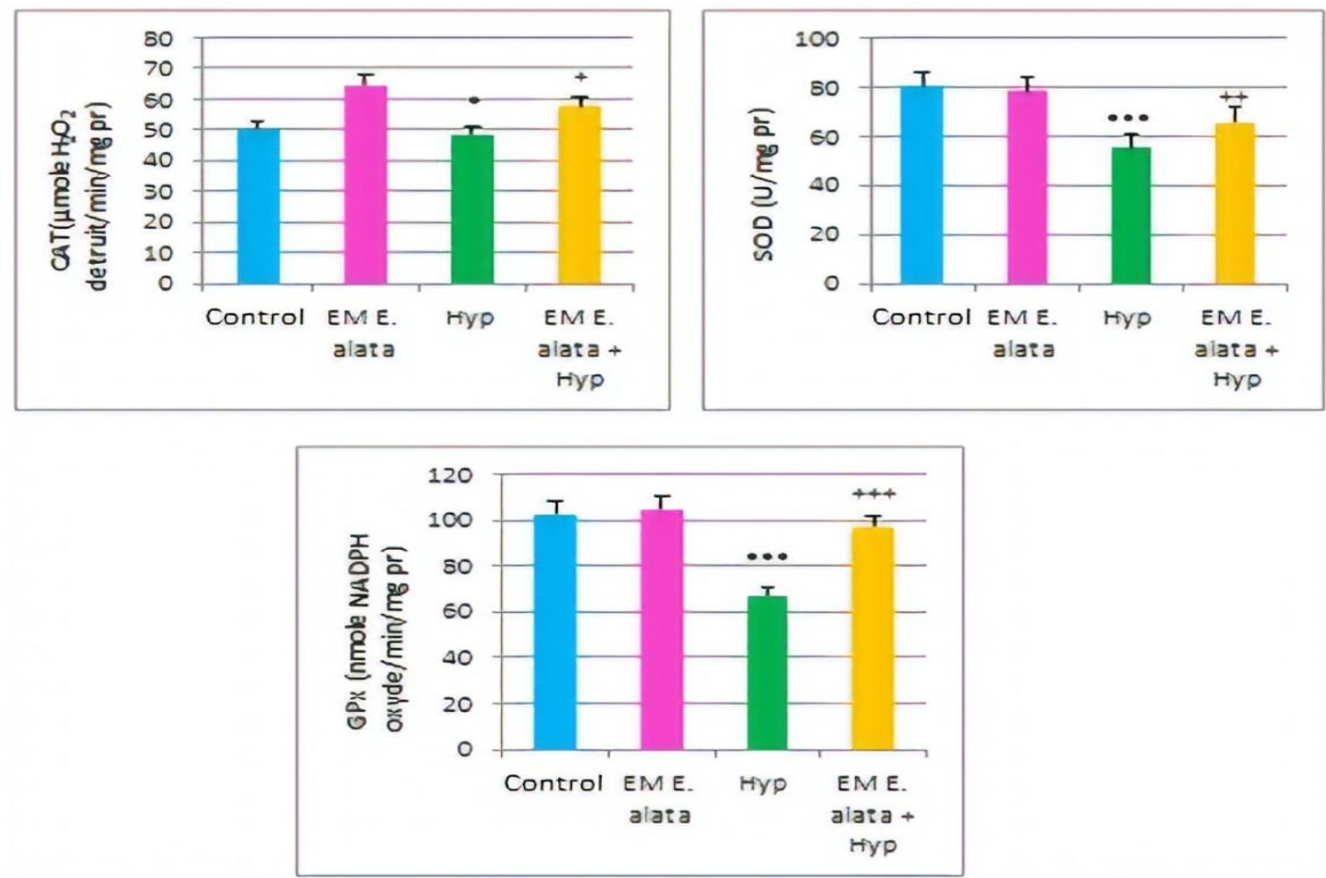

Figure 6.

Variations of SOD, CAT and GPx activities of the liver in the control and experimental groups

Values represented as mean $\pm \operatorname{SEM}(\mathrm{n}=6) ; *: \mathrm{p} \leq 0.05 ; * * * \mathrm{p} \leq 0.001$ compared to the normal control group; $+: \mathrm{p} \leq 0.05$; $++: p \leq 0.01$ and $+++: p \leq 0.001$ compared to the treated group (Нyp)

The results in Figure 6 showed a significant decrease in the activity of antioxidant enzymes SOD, CAT and
GPx in rats treated with Triton X-100 compared to the control cases. The results also showed that the 
acute treatment associated with pre-treatment with $E$ alata extract resulted in a clear restoration of the activity of these enzymes.

The increased activity of ALAT and ASAT in plasma is usually indicative of hepatic cytolysis [20]. The increase in ALAT and ASAT activity is an indicator of cell leakage and failure of the functional integrity of the membrane resulting from liver damage [32,44]. However, the group treated in parallel with Triton X-100 and EM E. alata (Hyp + EM E. alata) partially restored the enzymatic activity without reaching the values for the controls or those treated only with the extract of E. alata. This implies a potential hepatoprotective effect of the extract of E. alata probably due to a possible stabilization of the plasma membrane with replenishment of the liver tissue damage caused by the toxic agent, as has been suggested by other authors [41].

This anti-hyperlipidaemic effect can be explained by the ability of this extract to promote the inhibition of HMG-CoA reductase, to promote reactivity, causing a lipid-lowering effect [22].

The current data are in agreement with results previously reported $[1,8]$. The highly reactive oxygen metabolites, in particular hydroxyl radicals, act on membrane fatty acids, leading to the production of unstable lipid peroxides, which tend to decompose into products such as MDA [14].

The reduction decrease of SOD, CAT and GPx activities can only be due to the accumulation of reactive oxygen species which leads to harmful results, such as a decrease in the integrity of the cell membrane and loss of function [21]. Our results are in accordance with the work of Abdou RH et al. and Uchendu C et al. $[2,53]$ who described a decrease in the activity of antioxidant enzymes following exposure by Triton $\mathrm{X}-100$.

This protective effect could be caused by the indirect effect of the bioactive molecules present in E. alata which reduced the levels of reactive oxygen species. Indeed, antioxidant molecules can reduce lipid peroxidation by improving the activity of endogenous antioxidant enzymes [5, 52].

Histological study

Figure 7 shows histological sections stained with haematoxylin-eosin for the studied liver samples.

Our results show that in the control rats, the liver tissue is in the form of hexagonal hepatic lobules and each lobule is formed by well-anastomosed hepatocytes which are arranged in flattened spans around a centrallobular vein, and at the periphery. From each lobule are born sinusoids running between the hepatocyte lamina, each led by an endothelial cell reminiscent of an ordinary hepatic structure. However, the sections of the liver in the rats treated with the Triton X-100 showed remarkable changes, in comparison with those of the control, reflecting the presence of certain hepatocytes arranged irregularly and present a cytoplasmic vacuolization, a haemorrhage with congestion of the vein central, a large area of necrosis, dilated sinusoidal spaces, a high number of Kupffer cells, cellular infiltrations in the central vein of the lobules, as well as lipid foci.
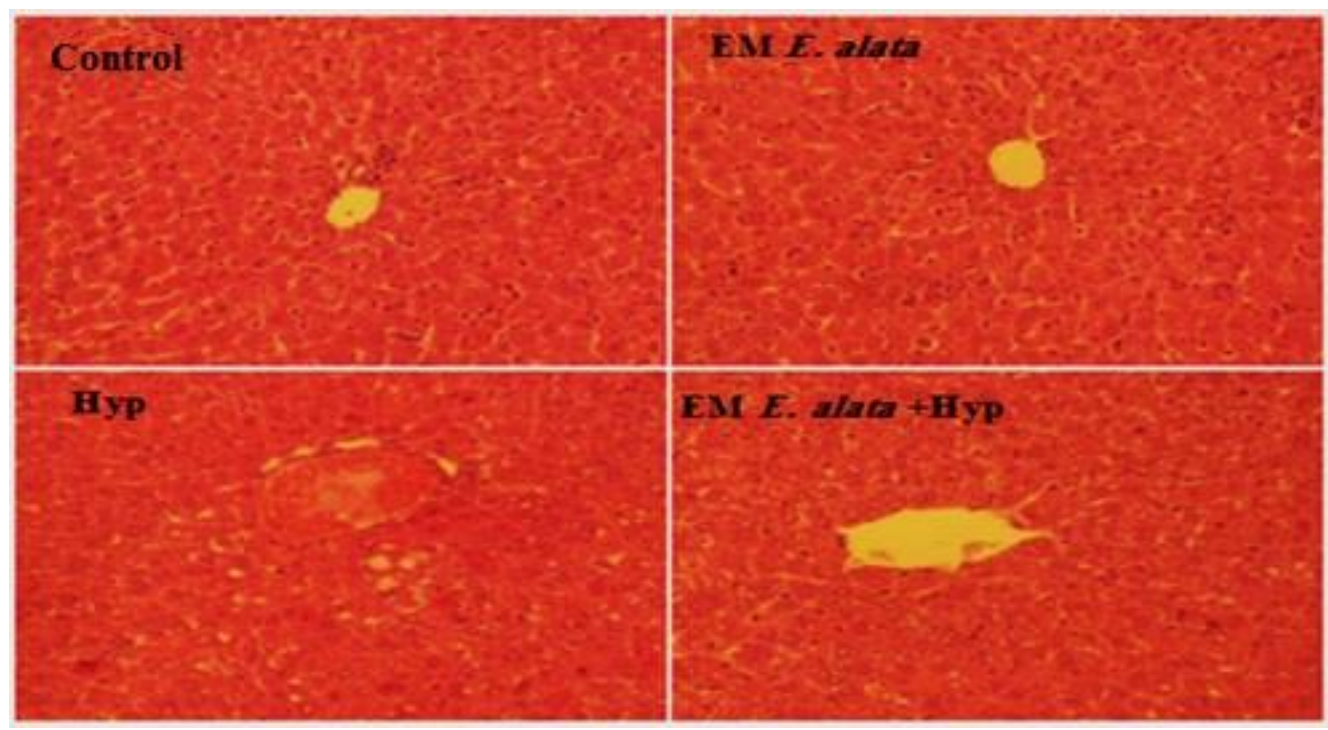

Figure 7.

Microscopic observation of a histological section of the liver (structural exploration) in the rats of different groups (x 400)

However, the combination of the methanol extract of E.alata (EM E. alata + Hyp) showed protection against the toxicity of Triton $\mathrm{X}-100$, which resulted in improved structural damage demonstrated in animals treated with Triton X-100 alone (Hyp), thus, we noted restoration of the architecture of hepatocytes with 
attenuation of the number of sinusoidal dilations and regression of the areas of necrosis and restoration of the number of Kupffer cells.

The histological sections stained with haematoxylineosin made in the liver, similar observations had been

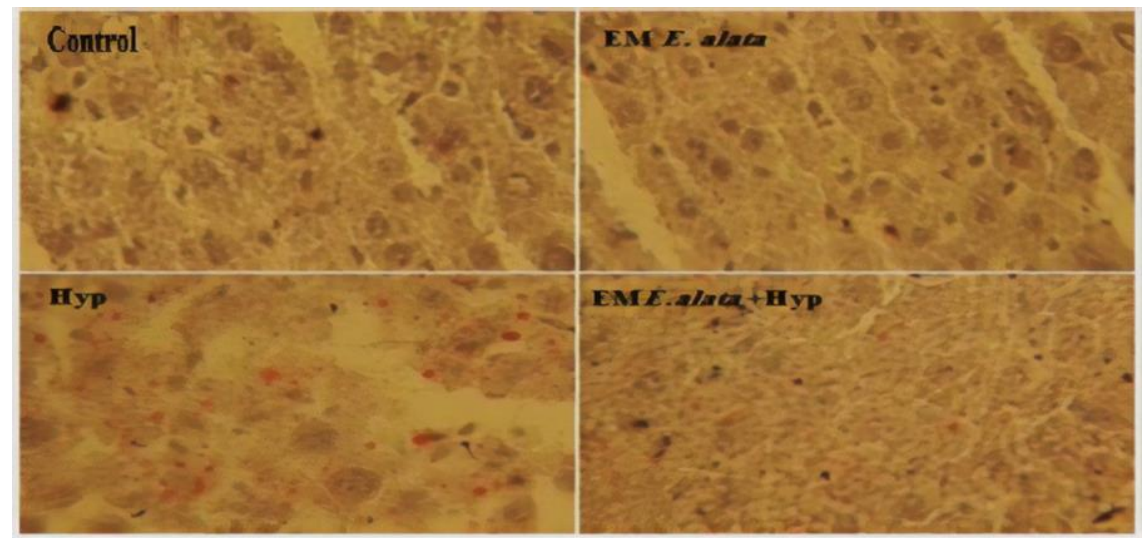

Figure 8.

Microscopic observation of a histological section of the liver (Histological exploration of the lipid deposition) in rats of different groups (x 400)

The histological sections made in the liver of the control rats and the rats pre-treated with the methanolic extract of Ephedra alata shows a normal structure of the hepatic parenchyma exhibiting small quantities of lipids distributed in the hepatocytes with a weak red coloration. However, a notable increase in lipid deposition was observed in the group treated with Triton X-100 compared to control rats, which is exerted by the increase in the intensity of the red coloration indicating the installation of a state of hyperlipidaemia in the liver.

This study revealed that the extract of E.alata protected the lipid disturbances induced by the Triton X-100, proved by other authors $[13,47,51]$ when treating rats with carbon tetrachloride.

In Figure 8, we used frozen sections using a cryostat to preserve the fatty deposits in the liver.

Effect of the methanol extract of Ephedra alata and Indomethacin on abdominal writhings induced by III

acid in rats

\begin{tabular}{|l|c|c|c|}
\hline \multicolumn{1}{|c|}{ Treatment } & Dose & Number of abdominal cramps & Inhibition (\%) \\
\cline { 2 - 4 } Control (acetic acid 0.1\%) & $10 \mathrm{~mL} / \mathrm{kg}$ & $26 \pm 1.32$ & $/$ \\
\hline Normal control (distilled water) & $5 \mathrm{~mL} / \mathrm{kg}$ & $26 \pm 1.32$ & 50 \\
\hline Indomethacin & $10 \mathrm{mg} / \mathrm{kg}$ & $13 \pm 1.06^{* *}$ & 30.7 \\
\hline EM E. alata & $50 \mathrm{mg} / \mathrm{kg}$ & $18 \pm 0.52^{*}$ & $/$ \\
\hline
\end{tabular}

Values represented as mean $\pm \operatorname{SEM}(\mathrm{n}=3) ;{ }^{*}: \mathrm{p} \leq 0.05 ;{ }^{*}: \mathrm{p} \leq 0.01$ compared to the normal control group

From these results, we can note the beneficial effect of the methanolic extract of female cones of Ephedra alata which induces a significant reduction in abdominal writhings compared to the control group. These values are similar to those obtained for indomethacin.

The appearance of abdominal torsions under the effect of acetic acid engages the effect of local peritoneal receptors [36] as well as the release of mediators such as prostaglandins and cytokines [35]. The analgesic effect of the extract, leaves us to suppose that the biomolecules contained in the female cones of Ephedra alata could inhibit the release of chemical mediators, as was also reported by Perz-Guerro C et al. [38].

\section{Conclusions}

The antioxidant activity of the extract from E. alata showed a higher inhibition of DPPH• free radical and the highest reductive activity. Also, the haemolysis test showed that the crude extract offered the best protection of erythrocytes. The HPLC analysis has identified eight phenolic compounds in the extract of E. alata: gallic acid, chlorogenic acid, vanillic acid, vanillin, p-coumaric acid, rutin, naringenin 
FARMACIA, 2020, Vol. 68, 6

and quercetin. The results of the protective effect of hyperlipidaemia caused by Triton X-100 showed that there are noticeable changes in the biochemical and oxidative stress parameters. The treatment with the methanol extract of Ephedra alata normalized the biochemical parameters and the stress state. The histological study confirmed the biochemical results. The values obtained for the methanolic extract of Ephedra alata regarding the analgesic activity are similar to those obtained for indomethacin.

\section{Conflict of interest}

The authors declare no conflict of interest.

\section{References}

1. Abdel-Daim MM, Abuzead SM, Halawa SM, Protective role of Spirulina platensis against acute deltamethrininduced toxicity in rats. PLoS One, 2013; 8(9): 1-7.

2. Abdou RH, Abdel-Daim MM, Alpha-lipoic acid improves acute deltamethrin-induced toxicity in rats. Can J Physiol Pharm., 2014; 92: 773-779.

3. Al-Qarawi AA, Abd Allah EF, Hashem A, Effect of Ephedra alata on nucleic acids and nitrogen metabolism of seedborne Aspergillus flavus. Pak J Bot., 2012; 44: 425-428.

4. AL-Qarawi AA, AbdAllah EF, Abeer H, Ephedra alata as biologically-based strategy inhibit aflatoxigenic seedborne mold. Afr J Microbiol Res., 2011; 5: 2297-2303.

5. Bansal AK, Bansal M, Soni G, Bhatnagar D, Protective role of Vitamin E pre-treatment on N-nitrosodiethylamine induced oxidative stress in rat liver. ChemBiol Interact., 2005; 156: 101-111.

6. Boudjouref M, Belhattab R, Bouteghrine S, Antioxidant activity and phenolic content of Artemisia campestris from two regions of Algeria. World J Environ Biosci., 2018; 7(2): 61-66.

7. Brand-Williams W, Cuvelier ME, Berset C, Use of a free radical method to evaluate antioxidant activity. LWT-Food Sci Technol., 1995; 28: 25-30.

8. Chargui I, Grissa I, Bensassi F, Hrira MY, Haouem S, Haouas Z, Bencheikh H, Oxidative stress, biochemical and histopathological alterations in the liver and kidney of female rats exposed to low doses of deltamethrin (DM): A Molecular Assessment. Biomed Environ Sci., 2012; 25(6): 672-683.

9. Chen WL, Tsai TH, Yang CCH, Kuo TBJ. Effects of ephedra on autonomic nervous modulation in healthy young adults. J Ethnopharmacol., 2010; 130: 563-568.

10. Chouikh A, Mekki M, Adjal EH, Effects of extraction methods on antibacterial activity of different extracts of Calligonum comosum L'her. growing in Sahara Algerian. Int J Recent Sci., 2015; 6(4): 3534-3536.

11. Chouikh A, Alia F, Neffar S, Rebiai A, Adjal E, Chefrour A, Evaluation of phenolic contents (quantitative and qualitative) and antioxidant activities in different physiological phases of Genista saharae Coss. \& Dur. growing in the Sahara of Algeria, Analele Univ din Oradea Fasc Biol., 2018; 25: 115-121.

12. Dolci A, Panteghini M, Harmonization of automated hemolysis index assessment and use: Is it possible?. Clin Chim Acta, 2014; 432: 38-43.
13. El-Haskoury R, Al-Waili N, Kamoun Z, Makni M, Al-Waili H, Lyoussi B, Antioxidant Activity and Protective Effect of Carob Honey in CCl4-induced Kidney and Liver Injury. Arch Med Res., 2018; 49(5): 306-313.

14. Esterbauer H, Dieber-Rotheneder M, Striegl G, Waeg G. Role of vitamin $\mathrm{E}$ in preventing the oxidation of low-density lipoprotein. Am J Clin Nutr., 1991; 53(1): 314s-321s.

15. Emsen B, The antioxidant and antigenotoxic potential of Peltigera canina and Umbilicaria nylanderiana based on their phenolic profile. Farmacia, 2019; 67(5): 912-921.

16. Gabe M. Techniques Histologiques. Masson. Paris, 1968, $1115 \mathrm{p}$.

17. García-Díaz JA, Navarrete-Vázquez G, García-Jiménez S, Hidalgo-Figueroa S, Almanza-Pérez JC, AlarcónAguilar FJ, Gómez-Zamudio J, Cruz M, Ibarra-Barajas M, Estrada-Soto S, Antidiabetic, antihyperlipidemic and anti-inflammatory effects of tilianin in streptozotocinnicotinamide diabetic rats. Biomed Pharmacother., 2016; 83: 667-675.

18. Ghedadba N, Hambaba L, Ayachi MC, Aberkane H, Bousselsela SM, Oueld- Moukhtar SM. Polyphénols totaux, activités antioxydant et antimicrobienne des feuilles de Marrubium deserti de Noé. Phytothérapie, 2015; 13: 118-129.

19. Govindwar SP, Dalvi RR, Stimulatory and inhibitory effects of dimethyl sulfoxide on microsomal aniline hydroxylase activity. Toxicol Lett., 1991; 55: 317-323.

20. Gowri Shankar NL, Manavalan R, Venkappayya D, David Raj C, Hepatoprotective and antioxidant effects of Commiphora berryi (Arn) Engl bark extract against $\mathrm{CCl}(4)$-induced oxidative damage in rats. Food Chem Toxicol., 2008; 46: 3182-3185.

21. Gundamaraju R, Hwi KK, Singla RK, Vemuri RC, Mulapalli SB, Antihyperlipidemic potential of Albizia amara (Roxb) Boiv. bark against Triton X-100 induced hyperlipidemic condition in rats. Pharmacogn Res., 2014; 6: 267-273.

22. Hao C, Hao J, Wang W, Han Z, Li G, Zhang L, Zhao $\mathrm{X}, \mathrm{Yu} \mathrm{G}$, Insulin sensitizing effects of oligomannuronatechromium (III) complexes in $\mathrm{C} 2 \mathrm{C} 12$ skeletal muscle cells. PLoS One. 2011; 6: 1-10.

23. Hegazi GAE, El-Lamey TM, In vitro Production of Some Phenolic Compounds from Ephedra alata Decne. J Appl Environ Biol Sci., 2011; 1: 158-163.

24. Jeong SM, Kim SY, Kim DR, Jo SC, Nam KC, Ahn DU, Lee SC, Effects of heat treatment on the antioxidant activity of extracts from Citrus peels. $J$ Agr Food Chem., 2004; 52: 3389-3393.

25. Khelef Y, Chouikh A, Rebiai A, Neffar S, Chefrour A, Adjal EH, Alia F, Biochemical, quantitative and qualitative phenolic compounds, anti-free radical's activities of Calligonum comosum collected from different sites in the Algerian Desert. Biharean Biol., 2019; 13(2): 71-76.

26. Koffi NG, Beugré K, Guédé NZ, Dossahoua T, Laurent AA, Screening phytochimique de quelques plantes médicinales ivoiriennes utilisées en pays Krobou (Agboville, Côte-d'Ivoire). Sciences \& Nature, 2009; 6: 1-15.

27. Konkon NG, Simaga D, Adjoungova AL, N, Guessan $\mathrm{KE}$, Zirihi CN, Kone BD. Etude phytochimique de 
FARMACIA, 2020, Vol. 68, 6

Mitragyna inermis (Willd.) O. Ktze (Rubiaceae), plante a feuille antidiabetique. Pharm Méd Trad Afr., 2006; 14: 73-80.

28. Kose K, Dogan P, Lipoperoxidation induced by hydrogen peroxide in human erythrocyte membranes. 1. Protective effect of Ginkgo biloba extract (EGb 761). J Int Med Res., 1995; 23(1): 1-8.

29. Koster R, Anderson M, De Beer EJ, Acetic acid for analgesic screening. Fed Proc., 1959; 18: 412-417.

30. Kumaran A, Karunakaran RJ, In vitro antioxidant activities of methanol extracts of five Phyllanthus species from India. LWT-Food Sci Technol., 2007; 40: 344-352.

31. Latifi E, Mohammadpour AA, H BF, Nourani H, Antidiabetic and antihyperlipidemic effects of ethanolic Ferula assa-foetida oleo-gum-resin extract in streptozotocin-induced diabetic wistar rats. Biomed Pharmacother., 2019; 110: 197-202.

32. Lin SC, Yao CJ, Lin CC, Lin YH, Hepatoprotective Activity of Taiwan Folk Medicine: Eclipta prostrata Linn. against Various Hepatotoxins Induced Acute Hepatotoxicity. Phytotherapy Research., 1996; 10(6): 483-490.

33. Luthria DL, Influence of experimental conditions on the extraction of phenolic compounds from parsley (Petroselinum crispum) flakes using a pressurized liquid extractor. Food Chem., 2008; 107(2): 745-752.

34. Mighri H, Bennour N, Eljeni H, Neffati M, Akrout A, Chromatography analysis of fatty acids, volatile compounds and alkaloids of Ephedra alata growing wild in Southern Tunisia and Evaluation of their Antioxidant Activity. Int J Pharmacogn Phytochem Res., 2017; 9(9): 1249-1259.

35. Negus SS, Vanderah TW, Brandt MR, Bilsky EJ, Becerra L, Borsook D, Preclinical assessment of candidate analgesic drugs: recent advances and future challenges. J Pharmacol Exp Ther., 2006; 319(2): 507-514.

36. Ouédraogo N, Lompo M, Sawadogo RW, Tibiri A, Hay AE, Koudou J, Etude des activités anti-inflammatoire, analgésique et antipyrétique des décoctés aqueux des feuilles et des racines de Pterocarpus erinaceus Poir. (Fabaceae). Phytothérapie, 2012; 10: 286-292.

37. Ould El Hadj MD, Hadj-Mahammed M, Zabeirou $\mathrm{H}$, place des plantes spontanées dans la médecine traditionnelle de la région de Ouargla (Sahara septentrional Est). Courrier du Savoir., 2003; 3: 47-51.

38. Perez-Guerrero C, Herrera MD, Ortiz R, de Sotomayor AM, Fernández MA. A pharmacological study of Cecropia obtusifolia Bertol aqueous extract. J Ethnopharmacol., 2001; 76(3): 279-284.

39. Perry JJP, Shin DS, Getzoff ED, Tainer JA, The structural biochemistry of superoxide dismutases. Biochim Biophys Acta, 2010; 1804(2): 245-262.

40. Peters CM, O'neill JO, Young JB, Bott-Silverman C, Is there an association between Ephedra and heart failure? A case series. J Card Fail., 2005; 11: 9-11.

41. Ravikumar S, Gnanadesigan M. Hepatoprotective and antioxidant activity of a mangrove plant Lumnitzera racemosa. Asian Pac J Trop Biomed., 2011; 1(5): 348-352.
42. Rjeibi I, Feriani A, Hentati F, Hfaiedh N, Michaud P, Pierre G, Structural characterization of watersoluble polysaccharides from Nitraria retusa fruits and their antioxidant and hypolipidemic activities. Int J Biol Macromol., 2019; 129: 422-432.

43. Saague PWK, Moukette Moukette B, Njimou JR, Biapa PCN, Nzufo Tankeu F, Moor VJA, Pieme CA, Ngogang JY, Phenolic Compounds from Water-Ethanol Extracts of Tetrapleura tetraptera Produced in Cameroon, as Potential Protectors against In Vivo CCl4-Induced Liver Injuries. Sci World J., 2019; 2019: 1-10.

44. Saraswat B, Visen PK, Patnaik GK, Dhawan BN, Anticholestatic Effect of Picroliv, Active Hepatoprotective Principle of Picrorhiza Kurrooa, Against Carbon Tetrachloride Induced Cholestasis. Indian J Exp Biol., 1993; 31(4): 316-318.

45. Siddhuraju P, Becker K. The antioxidant and free radical scavenging activities of processed cowpea (Vigna unguiculata (L.) Walp.) seed extracts. Food Chem., 2007; 101(1): 10-19.

46. Singleton VL, Rossi JA, Colorimetry of total phenolics with phosphomolybdic-phosphotungstic acid reagents. Am J Enol Vitic., 1965; 16(3): 144-158.

47. Sun J, Wu Y, Long C, He P, Gu J, Yang L, Liang Y, Wang Y, Anthocyanins isolated from blueberry ameliorates $\mathrm{CCl} 4$ induced liver fibrosis by modulation of oxidative stress, inflammation and stellate cell activation in mice. Food Chem Toxicol., 2018; 120 : 491-499.

48. Tabuti JRS, Lye KA, Dhillion SS, Traditional herbal drugs of Bulamogi, Uganda: plants, use and administration. J Ethnopharmacol., 2003; 88(1): 19-44.

49. Thammana M, A Review on High Performance Liquid Chromatography (HPLC). J Pharm Anal., 2016; 5(2): 22-23.

50. Timmermann BN, Steelin C, Loewus FA, Phytochemical Adaptations to Stress. CA: Plenum Press. New York, 1984, 348p.

51. Tlili N, Feriani A, Saadoui E, Nasri N, Khaldi A, Capparis spinosa leaves extract: Source of bioantioxidants with nephroprotective and hepatoprotective effects. Biomed Pharmacother., 2017; 87: 171-179.

52. Tsai CF, Hsu YW, Ting HC, Huang CF, Yen CC, The in vivo antioxidant and antifibrotic properties of green tea (Camellia sinensis, Theaceae). Food Chem., 2013; 136: 1337-1344.

53. Uchendu C, Ambali SF, Ayo JO, Esievo KA, The protective role of alpha-lipoic acid on long-term exposure of rats to the combination of chlorpyrifos and deltamethrin pesticides. Toxicol Ind Health., 2017; 33(2): 159-170.

54. Walum E, Acute oral toxicity. Environ Health Perspect., 1998; 106(Suppl 2): 497-503.

55. Yildirim A, Mavi A, Kara AA, Determination of antioxidant and antimicrobial activities of Rumex crispus L. extracts. J Agric Food Chem., 2001; 49(8): 40834089.

56. Zheng CD, Li G, Li HQ, Xu XJ, Gao JM, Zhang AL, DPPH-scavenging activities and structure-activity relationships of phenolic compounds. Nat Prod Commun., 2010; 5(11): 1759-1765. 